\title{
Hepatitis C and bleeding disorders in Europe
}

Laura Savini, Radoslaw Kaczmarek, Declan Noone, Paul Giangrande, Geoffrey Dusheiko, Brian O'Mahony

In the 1980s and 1990s, thousands of people with bleeding disorders (PWBD) across the world were infected with HIV and hepatitis $C$ virus (HCV) through contaminated treatment products. The extent of the infection, as well as the needs of those still living with $\mathrm{HCV}$, were never properly assessed. The purpose of our survey was to identify how many PWBD were infected with HCV in Europe, as well as their health status and needs. HCV infection was defined as any person with a bleeding disorder who was exposed to the virus and seroconverted to become anti-HCV antibody positive. The survey also looked at testing and treatment availability. Between December 2016 and March 2017, the survey was distributed to 45 national

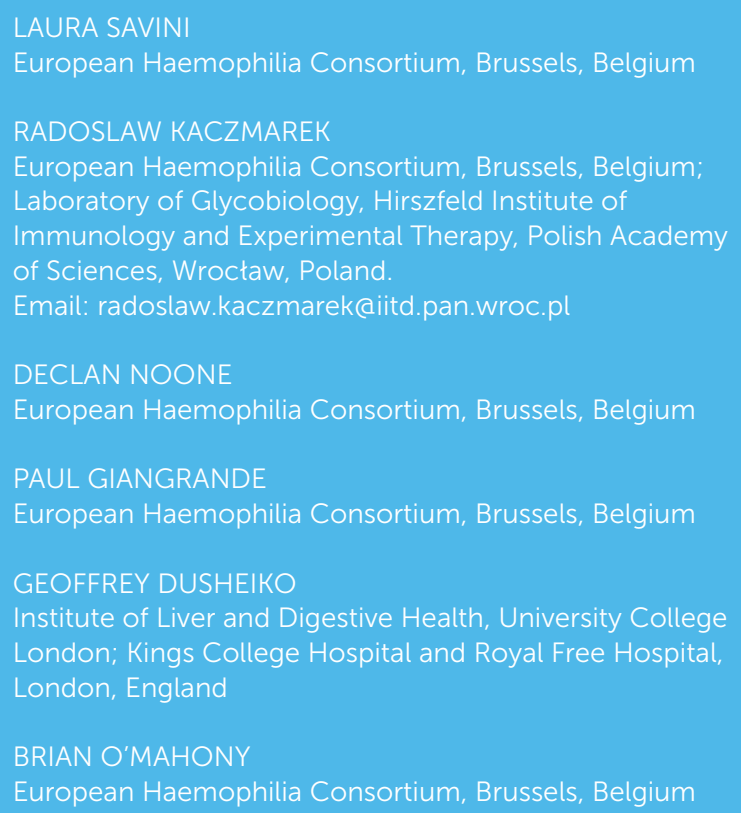

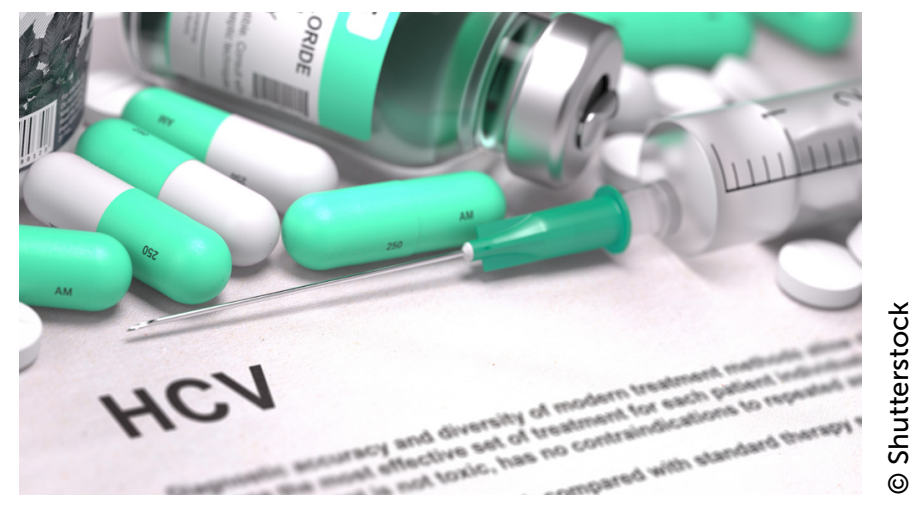

patient organisations in the European Haemophilia Consortium (EHC), who were encouraged to respond with the support of a local hepatologist. The data gathered led us to estimate that some 15,000 people with bleeding disorders were infected with $\mathrm{HCV}$ in the 30 countries that responded. Although some countries have detailed records of patients with $\mathrm{HCV}$, most - including some with national haemophilia registries - were unable to provide exact numbers of initial infections, HIV co-infection, survival and SVR rates. Responding countries reported varying degrees of monitoring for disease progression, as well as extremely divergent access to new direct-acting antivirals, with only eight countries prioritising PWBD for treatment. With liver disease and hepatocellular carcinoma being among the main causes of death in an aging bleeding disorders population, this survey identifies a clear gap in care. It is a frustrating paradox that today, in many European countries PWBD, such as haemophilia, may live long and productive lives due to much-improved access to factor replacement therapy, yet die prematurely of a curable disease such

This is an Open Access article distributed under the terms of the Creative Commons Attribution-NonCommercial-NoDerivs License (https://creativecommons.org/licenses/by-nc-nd/3.0/) which permits use and distribution in any medium, provided the original work is properly cited, the use is non-commercial, and no modifications or adaptations are made. Copyright is retained by the authors. 
as hepatitis $\mathrm{C}$. It has been demonstrated that HCV eradication in PWBD can be achieved through national commitment, especially when the patient population is limited and HCV eradication could be achieved in the short-term. The eradication of HCV in PWBD in Europe is an idea whose time has come.

Keywords: Bleeding disorders, Haemophilia, Hepatitis

C, Monitoring, Treatment

$n$ the 1980s and 1990s tens of thousands of people with bleeding disorders (PWBD) worldwide were infected with hepatitis $C$ virus (HCV) and human immunodeficiency virus (HIV) through their treatment products ${ }^{[1]}$. This medical disaster was the result of several factors, including lack of knowledge on the symptoms of HCV and HIV infections, and risks and modes of transmission; poor blood donor policies, which allowed high-risk populations to donate their blood and plasma for the production of plasma-derived therapies; the lack of viral inactivation techniques in the manufacturing process of plasma-derived medicines such as coagulation factor concentrates and cryoprecipitate; and inaction in response to emerging safety signals from both regulatory agencies and healthcare professionals ${ }^{[2]}$. In addition, there was a reluctance to acknowledge that coagulation factor concentrates, being the most efficacious life-saving medicines for PWBD, could themselves be significant causes of mortality.

Although it is clear that the effects of the contamination of plasma products have been devastating for the bleeding disorders community worldwide, they have never been properly quantified in many regions, including Europe. Haemophilia and other bleeding disorders are still not properly diagnosed and treated in many countries, including many in the European region ${ }^{[3,4]}$. For individuals affected by a bleeding disorder such as haemophilia, HIV or HCV were and continue to be associated with stigma and discrimination, often inhibiting individuals affected by these conditions from disclosing their health status. Also, not all countries in Europe are equipped with centralised record systems, such as a national registry, to monitor the health status of their rare bleeding disorders population.

With previous hepatitis $C$ treatments (interferon and ribavirin) having low success rates, the advent of directacting antivirals (DAAs) has given hope to those affected by HCV and bleeding disorders to achieve sustained virologic response (SVR). SVR means effectively curing these patients as long as they complete treatment, thus reducing the risk of advancing fibrosis, hepatocellular carcinoma, cirrhosis and/or liver failure ${ }^{[5]}$. SVR may also lead to regression of fibrosis and improvement in liver function ${ }^{[6]}$. Furthermore, treatment regimens today, including second-generation DAAs, generate close to $100 \%$ SVR rates ${ }^{[7]}$.

HIV co-infection may exacerbate the clinical progression of hepatitis $C$ in PWBD, along with repeated exposure to HCV through contaminated products as treatment for bleeding episodes ${ }^{[8,9]}$. Conversely, a patient's haemophilia could later be exacerbated by HCV due to a failing liver and issues with other clotting proteins. Therefore, PWBD who have been living with HCV for over 30 years may face a greater risk of deterioration of liver health unless they receive appropriate treatment ${ }^{[9,10]}$.

The European Haemophilia Consortium (EHC) is an international non-profit organisation representing 45 national patient associations for people with bleeding disorders (PWBD) across Europe. In 2016 the EHC carried out a survey on the health status of PWBD affected by HCV in Europe, with the aim of identifying the number of people infected and their health status and mapping their needs onto existing information on access to hepatitis $C$ treatments. The survey also looked at testing and treatment availability.

\section{METHODS}

Between December 2016 and March 2017, the EHC developed and sent out a questionnaire to its 45 national member organisations (NMOs). The questionnaire (reproduced in full in the appendix to this article, Figure A1) consisted of 17 questions and was developed by members of the EHC Steering Committee, members of the EHC Data and Economics Committee, other EHC staff and a hepatologist. EHC NMOs were asked to respond to the questionnaire together with the support of local clinicians. The questionnaire was available in both English and Russian, and focused on three main areas: identifying the patient population with bleeding disorders infected with $\mathrm{HCV}$ within each country; the viral status of those currently living with $\mathrm{HCV}$; and the care and treatment available to PWBD with HCV. HCV infection was defined as any person with a bleeding disorder who was exposed to the virus and seroconverted to become HCV antibody (anti-HCV) positive, irrespective of whether they later cleared the virus spontaneously or achieved an SVR through treatment (thus becoming anti-HCV positive and PCR negative) 
Table 1: List of countries that provided or did not provide data

\begin{tabular}{|c|c|}
\hline $\begin{array}{l}\text { COUNTRIES THAT } \\
\text { PROVIDED DATA }\end{array}$ & $\begin{array}{l}\text { COUNTRIES THAT DID } \\
\text { NOT PROVIDE DATA }\end{array}$ \\
\hline Albania & Armenia \\
\hline Austria & Belgium \\
\hline Azerbaijan & Croatia \\
\hline Belarus & Estonia* \\
\hline Bosnia \& Herzegovina & Georgia \\
\hline Bulgaria & Iceland \\
\hline Cyprus & Israel \\
\hline Czech Republic & Kyrgyzstan \\
\hline Denmark & Luxembourg \\
\hline Finland & Moldova \\
\hline France & Norway \\
\hline Germany & Russia* \\
\hline Greece & Serbia \\
\hline Hungary & Spain \\
\hline Ireland & Turkey \\
\hline \multicolumn{2}{|l|}{ Italy } \\
\hline \multicolumn{2}{|l|}{ Latvia } \\
\hline \multicolumn{2}{|l|}{ Lithuania } \\
\hline \multicolumn{2}{|l|}{ Macedonia } \\
\hline \multicolumn{2}{|l|}{ Montenegro } \\
\hline \multicolumn{2}{|l|}{ Poland } \\
\hline \multicolumn{2}{|l|}{ Portugal } \\
\hline \multicolumn{2}{|l|}{ Romania } \\
\hline \multicolumn{2}{|l|}{ Slovakia } \\
\hline \multicolumn{2}{|l|}{ Slovenia } \\
\hline \multicolumn{2}{|l|}{ Sweden } \\
\hline \multicolumn{2}{|l|}{ Switzerland } \\
\hline \multicolumn{2}{|l|}{ The Netherlands } \\
\hline \multicolumn{2}{|l|}{ UK } \\
\hline Ukraine & \\
\hline
\end{tabular}

*Estonia and Russia responded, but were not able to provide any data

\section{RESULTS}

Response rate

Of the $45 \mathrm{EHC}$ members surveyed, 30 (67\%) provided data (see Table 1). Responses came from 22 countries within the European Union (EU) and eight countries outside the EU but in the Council of Europe. The majority of the answers to individual questions were incomplete, and only ten countries (Cyprus, Czech Republic, France, Germany, Ireland, Lithuania, Montenegro, Portugal, Slovenia and Sweden) were able to provide answers to all questions, although some of these consisted of estimates or anecdotal information. An overview of the data provided in responses to questions 4 to 7 of the questionnaire, showing which countries were able to provide data, and whether these were exact figures or estimates, is provided in the appendix (Tables A1-A3).

For six countries, the questionnaire was completed by a healthcare professional (Albania, Cyprus, Germany, Slovakia, Slovenia and Ukraine). For France the questionnaire was jointly submitted by a healthcare professional and a NMO representative. For Montenegro the questionnaire was submitted by a patient and NMO representative who is also a healthcare professional. For the Czech Republic the questionnaire was submitted by a project manager working at the national haemophilia register. For the remaining 21 countries the questionnaire was submitted by NMO representatives.

Hepatitis C prevalence in people with bleeding disorders In terms of PWBD who were infected with $\mathrm{HCV}$, ten countries (Austria, Denmark, France, Hungary, Ireland, Montenegro, the Netherlands, Slovakia, Slovenia and Sweden) stated they were able to provide exact figures, seven of which reported their data came from a national registry (Austria, Ireland, France, Montenegro, Slovakia, Slovenia and Sweden). Data reported from the Netherlands came from national surveys or clinical research ${ }^{[11]}$. For Denmark and Hungary, the data source was not specified.

Eighteen countries gave estimates in numbers or a percentage of a given population (e.g. adult). Data for these countries came from a variety of sources, including national registries, patient organisation records, treatment centres, patient records, scientific publications, and anecdotal information collected by the patient organisation ${ }^{[12]}$. Respondents in Latvia and Poland reported that they had no data on this topic.

Taken together, a total of 4,751 PWBD were infected with $\mathrm{HCV}$ in the ten countries that provided exact numbers. Using reports from the EHC and the World Federation of Hemophilia (WFH) on current numbers of PWBD, and estimates provided in other responses to the questionnaire, a further 11,000 patients could have been infected in the remaining 18 countries that were unable to provide exact numbers ${ }^{[3,4]}$.

\section{Health status of people with bleeding disorders infected with HCV}

\section{HIV infection}

21 countries provided numbers on HCV and HIV coinfection in their bleeding disorder population. Eleven countries had $<11 \%$ HIV infection rate (Albania, Czech Republic, Hungary, Lithuania, Macedonia, Montenegro, 
Figure 1: Health status of PWBD infected with HCV in the Czech Republic, Ireland, Slovakia, Slovenia and Sweden*

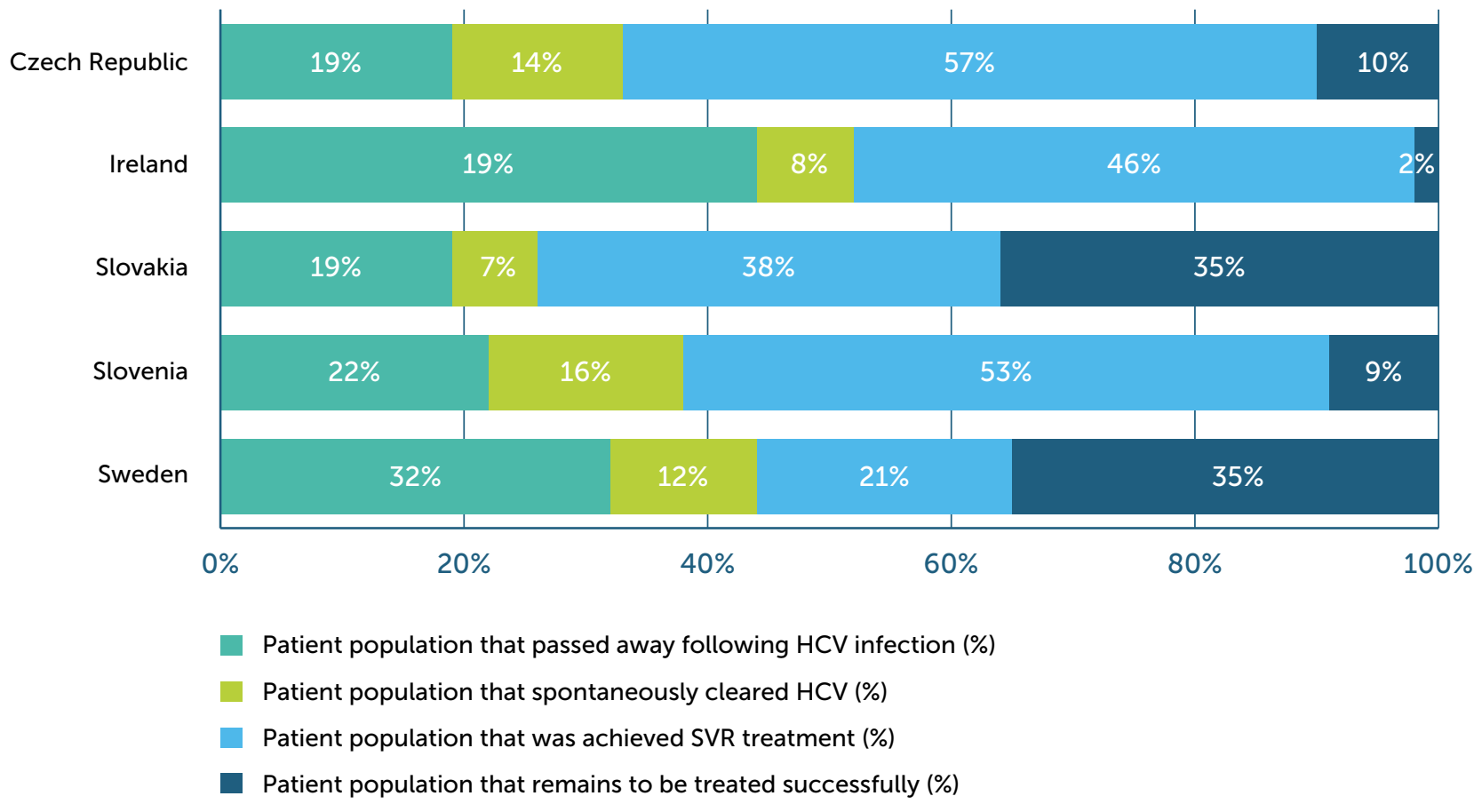

\footnotetext{
* Only the five countries represented in this chart were able to provide complete and accurate data in response to questions concerning the health status of PWBD infected with HCV
}

Slovakia and Ukraine (1\%); Finland (2\%); Slovenia (7\%); Cyprus (11\%)). In the remaining ten countries, HIV infection ranged from $24 \%$ to $51 \%$ (Austria, Sweden and France, 24\%; Italy 25\%; Greece and Portugal, 30\%; Germany 33\%; Ireland 44\%; the UK 50\%; Denmark 51\%).

\section{Survival rate}

When asked how many of the PWBD who were infected with HCV survived (i.e. the total number of PWBD infected with HCV, less those who died after contracting the virus), 21 countries were unable to provide reliable figures. Five countries reported that over $75 \%$ of the population survived (Cyprus $89 \%$; Czech Republic and Slovakia, 81; Italy and Slovenia, $78 \%$ ). Germany and Sweden reported survival rates of $68 \%$; Ireland reported 56\%; and Greece reported 54\%.

\section{Sustained Virologic Response (SVR)}

Survey respondents were asked to provide figures or estimates of PWBD infected with HCV who: a) spontaneously cleared the infection, b) achieved SVR through treatment, and c) remained to be cured (i.e. those who have been treated but have not achieved SVR). Only five countries (Czech Republic, Ireland, Slovakia, Slovenia and Sweden) provided complete and precise data (see Figure 1).
Fourteen countries provided a figure for patients that had spontaneously cleared $\mathrm{HCV}$, ranging from 0\% in Montenegro to 30\% in Hungary (Montenegro, Azerbaijan, Slovakia, Ireland, Lithuania, Bulgaria, Sweden, Czech Republic, the Netherlands, the UK, Slovenia, Germany, Greece, Hungary). The authors are not aware of any literature discussing the reasons for the difference in spontaneous clearing between countries. However, this may be as a result of differences in the size of population in different countries and, as a result, the figures for some countries being more statistically robust than others.

Sixteen countries provided SVR rates (Azerbaijan, Cyprus, Bulgaria, Czech Republic, Denmark, Germany, Greece, Hungary, Ireland, Lithuania, Macedonia, Montenegro, Portugal, Slovakia, Slovenia, Sweden) based on either interferon-based therapy or new DAAs, varying from $0.23 \%$ in Azerbaijan to $95 \%$ in Portugal, where an aggressive national programme was rolled out to treat all patients with $\mathrm{HCV}$. With regard to the as yet uncured population, 20 countries were able to provide an answer. This figure ranged from $9 \%$ in Slovenia to $56 \%$ in Bulgaria. The remaining ten countries were unable to provide an answer (Austria, Azerbaijan, Bosnia and Herzegovina, Latvia, Macedonia, the Netherlands, Poland, Romania, Switzerland, the UK). 
Table 2: Frequency of testing of progression of liver disease

\begin{tabular}{l|l|l|l}
\hline EVERY SIX MONTHS & ANNUALLY & EVERY TWO YEARS & NOT TESTED ROUTINELY \\
\hline Albania & Czech Republic & Cyprus & Austria \\
\hline France & Denmark & Finland & Belarus \\
\hline Germany & Italy & The Netherlands & Poland \\
\hline Hungary & Latvia & & Ukraine \\
\hline Ireland & Lithuania & & \\
\hline Portugal & Macedonia & & \\
\hline Slovakia & Sweden & & \\
\hline Slovenia & & & \\
\hline
\end{tabular}

\section{Monitoring liver health}

Survey participants were asked whether PWBD and $\mathrm{HCV}$ were routinely monitored for progression of liver disease. Twenty-three countries replied that PWBD and HCV were routinely tested. Four countries noted that this patient population was not routinely tested (Austria, Belarus, Poland and Ukraine). Three countries did not provide a response to this question (Bosnia and Herzegovina, Romania and Switzerland). With regard to frequency of testing (Table 2), eight countries reported that tests were conducted every six months; seven countries reported that tests were conducted annually; and three countries reported that tests were conducted every two.

In five countries, testing frequency was dependent on clinical and other factors. In Greece, for example, patients are tested every two years, unless they are also co-infected with HIV, in which case they are tested annually. In the Netherlands patients are tested every two years, unless the clinical situation of the patient requires more regular testing. In the UK, testing frequency depends on the treatment centre, but the most common frequency is annually. In Montenegro, patients are tested at the beginning and end of hepatitis $C$ treatments. In Latvia, in addition to annual tests, patients are also tested whenever they switch to a different coagulation factor concentrate. Finally, in Bulgaria, there is no standard frequency for testing. Ten countries did not report on testing frequency (Austria, Azerbaijan, Belarus, Bosnia and Herzegovina, Estonia, Poland, Romania, Russia, Switzerland and Ukraine).

Thirteen countries (Albania, Bulgaria, Czech Republic, France, Greece, Lithuania, Macedonia, Montenegro, the Netherlands, Slovakia, Slovenia, Sweden and the UK) reported using multiple testing methods to monitor liver disease progression. Blood tests (AST, ALT, AFP, GGT, bilirubin) are used for routine monitoring. A FibroTest ${ }^{\circledR}$ score is calculated by six countries (Bulgaria, Lithuania, France, Macedonia, Slovenia and Sweden) with additional criteria (including albumin and platelet count) for monitoring purposes. Latvia reported using blood tests exclusively for tracking liver health. FibroScan ${ }^{\circledR}$ was reported to be used by 20 countries with nine countries (Cyprus, Denmark, France, Finland, Germany, Hungary, Ireland, Italy and Portugal) utilising this test as the primary method of monitoring liver health. Montenegro reported that liver biopsy was also used. Other monitoring methods included ultrasound.

\section{Liver health}

Survey participants were asked to provide information on how many people had either had a liver transplant or had developed hepatocellular carcinoma (HCC). With regard to liver transplant, 15 countries responded. In six countries $0 \%$ of the patient population had received a liver transplant (Cyprus, Lithuania, Montenegro, Slovakia, Slovenia and Ukraine). In six countries the rate was approximately 1\% (France, Finland, Germany, Greece, Hungary, Italy). In the Czech Republic the rate was $1.4 \%$. Ireland had the highest rate at $3.75 \%$. Portugal reported anecdotal information of three known patients who had received a liver transplant (which would equate to approximately $2 \%$ ).

With regard to HCC, 12 countries responded. Lithuania and Montenegro reported that no patients had developed HCC (0\%), while Slovakia and Slovenia reported that under $2 \%$ of the population had developed HCC. Five countries reported that 2-3\% of the patient population had developed HCC (Czech Republic, France, Greece, Germany and Hungary). Ireland and Portugal reported that up to $5 \%$ of the population developed liver cancer. Cyprus reported the highest rate at $11 \%$, however this is primarily due to small sample size. 
Table 3: Availability of treatment products and level of reimbursement

\begin{tabular}{|c|c|c|c|c|}
\hline & $\begin{array}{l}\text { PEG- } \\
\text { INTERFERON } \\
+ \text { +RIBAVIRIN }\end{array}$ & $\begin{array}{l}\text { PEG- } \\
\text { INTERFERON } \\
+ \text { RIBAVIRIN+ } \\
\text { TELAPREVIR/ } \\
\text { BOCEPREVIR }\end{array}$ & $\begin{array}{l}\text { PEG- } \\
\text { INTERFERON } \\
\text { +RIBAVIRIN } \\
\text { +SOFOSBUVIR }\end{array}$ & $\begin{array}{l}\text { SECOND } \\
\text { GENERATION } \\
\text { DAAS* }\end{array}$ \\
\hline $\begin{array}{l}\text { Is available in my country and it is fully covered by } \\
\text { the national healthcare system }\end{array}$ & 24 & 7 & 17 & 19 \\
\hline $\begin{array}{l}\text { Is available in my country and the patient needs } \\
\text { to partially pay for this treatment }\end{array}$ & 2 & 0 & 0 & 1 \\
\hline $\begin{array}{l}\text { Is available in my country but the patient needs to } \\
\text { fully pay for its treatment }\end{array}$ & 0 & 11 & 3 & 1 \\
\hline Is not available in my country & 0 & 2 & 1 & 3 \\
\hline
\end{tabular}

* sofosbuvir, velpatasvir, elbasvir, grazoprevir, daclatasvir, ombitasvir, paritaprevir+ritonavir, dasabuvir, ledipasvir

\section{Hepatitis C treatments}

Survey participants were asked to identify which hepatitis $C$ treatments are available in their countries as well as the level of reimbursement (see Table 3). The oldest and hence most available treatment is PEG-interferon with ribavirin, which is available in 26 countries and fully reimbursed in 24 countries. In Belarus and Ukraine, the treatment is available but copayment from the patient is required.

PEG-interferon with ribavirin with first-generation DAAs (telaprevir or boceprevir) is available in 18 countries. It is fully reimbursed in seven countries (Austria, Greece, France, Italy, Lithuania, Poland and Slovakia). It is available but not reimbursed in 11 countries. This treatment is not available in two countries (Finland and Macedonia).

PEG-interferon with ribavirin combined with sofosbuvir is available in 20 countries. It is fully reimbursed in 17 countries. It is available but not reimbursed in three countries (Albania, Austria and Ukraine). It is not available in Macedonia.

Combinations of second generation DAAs are available in 21 countries. In 19 countries the treatment is fully reimbursed by the national healthcare system. In Montenegro, the treatment is available, however the patient must contribute to the cost of the treatment. In Austria patients can access treatment, however the full cost has to be paid by the individual. The treatment is not available in Albania, Macedonia, and Ukraine.

Additionally, as shown in Table 4, the Czech Republic, Cyprus, Denmark, Finland, Germany, Greece, Hungary and Ireland reported on patients with bleeding disorders and HCV achieving SVR with secondgeneration DAAs to date (either provided by the government programmes or clinical trials).
Survey participants were also asked whether patient access to these treatments is prioritised based on disease progression and/or having a bleeding disorder. Patients are prioritised based on the progression of liver disease in 21 countries. This is not the case in six countries (Albania, France, Germany, Lithuania, Montenegro and the Netherlands). PWBD are prioritised in eight countries (Austria, Bosnia and Herzegovina, Cyprus, Finland, Hungary, Ireland, Italy and Lithuania).

Finally, 15 countries reported that they had a national hepatitis $C$ treatment programme (Cyprus, Finland, France, Hungary, Ireland, Italy, Latvia, Lithuania, Montenegro, Poland, Portugal, Slovakia, Slovenia, Sweden and Ukraine). Ten countries noted that they did not have such a programme, and seven countries reported no information on this.

Participants were asked where hepatitis C treatment is administered in the country. Twenty-

Table 4: Percentage of PWBD with HCV achieving SVR with second-generation DAAs

\begin{tabular}{ll} 
& $\begin{array}{l}\text { PWBD ACHIEVING } \\
\text { SVR WITH SECOND- } \\
\text { GENERATION DAAS (\%) }\end{array}$ \\
\hline Germany & 40 \\
\hline Ireland & 24 \\
\hline Cyprus & 11 \\
\hline Denmark & 8 \\
\hline Czech Rep. & 5 \\
\hline Hungary & 4 \\
\hline Greece & 3 \\
\hline Finland & 3 \\
\hline
\end{tabular}


seven countries reported on this (Azerbaijan, Romania and Switzerland did not respond). In 11 countries (Bulgaria, Finland, Greece, Hungary, Lithuania, the Netherlands, Poland, Portugal, Slovenia, Sweden and Ukraine) administration of treatment may be provided by more than one service. Hepatitis $C$ treatment is most commonly administered in specialised hepatology, gastroenterology and infectious disease services in hospitals (26 countries). In Lithuania and Poland, treatment can be prescribed by a general practitioner. Seven countries reported that treatment can be administered through the haemophilia treatment centre (Bulgaria, Greece, Hungary, Lithuania, Portugal, Sweden and Ukraine).

\section{Hepatitis C treatment cost}

Survey participants were asked about the current cost of a 12-week treatment course for sofosbuvir or sofosbuvir/ledipasvir as an indicator of current payment levels for second-generation DAAs. 19 countries responded, of which 16 reported prices. For a 12-week treatment course with sofosbuvir, the median price was $€ 37,000$ (range $€ 15,000-€ 54,000$ ), and the median price for a 12-week treatment course with sofosbuvir/ ledipasvir was $€ 40,000$ (range $€ 14,000$ - $€ 54,000$ ). Twelve countries reported that bulk price negotiations for the purchase of second-generation DAAs have been carried out in their country, and that prices may be significantly different to actual prices paid (which were not available due to commercial sensitivity).

Financial compensation for people infected with HCV Survey participants were asked to specify whether PWBD who had been infected with $\mathrm{HCV}$ had received financial compensation (see Table 5). All those

Table 5: Countries where PWBD infected with HCV have been compensated

\begin{tabular}{|c|c|c|}
\hline ALL PWBD & SOME PWBD & $\begin{array}{l}\text { NEVER } \\
\text { COMPENSATED }\end{array}$ \\
\hline Cyprus & Albania & Austria \\
\hline France & Germany & Czech Republic \\
\hline Hungary & UK & Denmark \\
\hline Ireland & Italy & Greece \\
\hline \multirow[t]{6}{*}{ Sweden } & & Macedonia \\
\hline & & Montenegro \\
\hline & & The Netherlands \\
\hline & & Portugal \\
\hline & & Slovakia \\
\hline & & Slovenia \\
\hline
\end{tabular}

infected in Cyprus, France, Hungary, Ireland and Sweden received some form of compensation. No compensation was provided in ten countries (Austria, Czech Republic, Denmark, Greece, Macedonia, Montenegro, the Netherlands, Portugal, Slovakia, and Slovenia). Variable forms of compensation were offered in other countries. In the UK, for example, financial support was given to most of those infected, except those who spontaneously cleared the virus; while in Germany only those co-infected by HIV were compensated. An estimated $10 \%$ of the infected population in Albania received some compensation. In Italy $37 \%$ of those infected received some compensation in 2004, and there is an ongoing lawsuit for an estimated $17 \%$ of the infected population. Respondents did not provide details as to why only a certain percentage of the infected population received compensation.

\section{DISCUSSION}

As highlighted by other authors, the infection of tens of thousands of PWBD with HCV through their treatment is one of the largest medical treatment disasters in history ${ }^{[1]}$. A new paradigm in treatment regimens may create the opportunity for the eradication of HCV from the bleeding disorders community. Data reported to European Haemophilia Safety Surveillance (EUHASS) show that hepatocellular cancer is the most common cancer in patients with haemophilia, and liver disease is the most common cause of death in these individuals. In Ireland and Portugal we have seen the dramatic eradication of HCV either through the prioritisation of PWBD or a dedicated national commitment to the eradication of the virus, respectively ${ }^{[13-15]}$. It is in support of the objective of eradication of HCV in PWBD in Europe that this survey aims to identify the gaps in care, access and monitoring of hepatitis $C$ in this population. The importance of this objective was recognised by the European Directorate for the Quality of Medicines and Healthcare (EDQM) of the Council of Europe in their 2016 recommendation, which states: "Treatment for hepatitis $C$ with direct-acting antiviral agents should be provided to all people with haemophilia on a high priority basis." [16]

Data on the initial prevalence of HCV infections in PWBD, co-infection of HIV, survival rates and SVR varies significantly across Europe. Also, the data provided in relation to the number of PWBD infected with HCV needs to be interpreted with a degree of caution. For example, in the case of Ireland, because of the existence of a specific database for patients ${ }^{[9]}$, it 
is probable that numbers reported include those who were co-infected with HIV and may have died prior to being diagnosed with hepatitis $C$.

Only five of the 30 countries that responded to the survey were able to provide an accurate breakdown of initial infections, co-infection with HIV, historic deaths due to hepatitis $C$, treatment success and ability to identify patients who still require treatment. Four countries were unable to provide any data on hepatitis $C$ prevalence in the PWBD population. In the remaining 18 countries, information is estimated based on best available information. It is also important to note that the variations in infected population are related to the size of the bleeding disorders population as well as the type, quality and quantity of access to clotting factor concentrates. For example, Montenegro reported that only two PWBD were infected with $\mathrm{HCV}$, while the UK reported an estimated 3,000 patients infected. Interestingly, with data collected in a 2012 survey, 14 of the 22 countries who were unable to provide accurate data, were countries with a national haemophilia registry ${ }^{[3]}$. This identifies a clear gap in comprehensive care, especially considering the rates of hepatocellular carcinoma and deaths related to HCV that could be used to accurately identify patients with HCV. Countries with national registries may be comforted by their ability to track annual bleeding rates (ABR), but it is just as important for them to have an accurate picture of hepatitis $C$ in PWBD, not least because it is the leading cause of mortality in this population in Western Europe ${ }^{[1]}$.

The rate of HIV co-infection ranges from $1 \%$ in the Czech Republic, Hungary and Ukraine to $51 \%$ in Denmark. The most probable explanation for such variations is access to different treatment products at the height of the treatment-related infections. While clotting factor concentrates were the predominant treatment in Western Europe, fresh frozen plasma or cryoprecipitate predominated in Central and Eastern Europe due to restrictions on the purchase of US plasma sourced concentrates prior to 1989 . This changed with the concurrent fall of the Berlin Wall and the discovery of $\mathrm{HCV}$ and its identification as the culprit of what was then known as non-A/non-B (NANB) hepatitis.

In four countries (Austria, Belarus, Poland and Ukraine) testing for $\mathrm{HCV}$ is not part of the routine review for $\mathrm{PWBD}$. Of more interest is that it is a routine component of care in 22 countries, yet despite this a limited number of countries were able to provide accurate data on infection status in PWBD. There is a significant disconnect between the data available in patient records and how this should be used to monitor what is clearly a significant cause of patient mortality.

In terms of testing, the movement away from liver biopsy as the "gold standard" towards FibroScan ${ }^{\circledR}$ makes identifying current levels of liver damage in patients significantly easier. Twenty countries use this as a routine way of monitoring PWBD who are infected with HCV. Due to the potential complications with haemophilia, liver biopsy is now rarely used as a testing standard. Of the countries that responded to the survey, there is some disparity in monitoring timings, with 44\%, $39 \%$ and $17 \%$ of countries monitoring every six months, annually, and biennially, respectively. However, it was not reported whether there was a stratification for those with more advanced fibrosis or cirrhosis.

The development of DAAs, resulting in greatly increased probability of SVR, reduction in treatment duration with specific stop and extension rules and significantly reduced side effects, allows for a paradigm shift in the availability of treatment. In $81 \%$ of the countries that responded to the survey, treatment is provided through the traditional specialties of hepatology, gastroenterology and infectious disease clinics. In Lithuania and Poland (6\% of the responding countries) treatment is available through general practitioners. Interestingly, in $23 \%$ of the countries that responded to the survey, patients may avail of therapy through haemophilia treatment centres. This has significant benefits, as they are often the key point of contact for patients with bleeding disorders and their respective healthcare systems. The task shifting of $\mathrm{HCV}$ treatment to non-specialist providers, which may or may not be overseen by hepatologists, may improve access to treatment and help bridge the remaining gaps $^{[17]}$. This has become more practical given the much lower side-effect profile of second-generation DAAs compared to previous therapies. ${ }^{[18]}$

As highlighted internationally, cost implications are the greatest impediment to the treatment of those with HCV, with costs differing up to five-fold between countries for some products. This level of disparity puts patients at risk in two ways. Firstly, it limits access to treatment in the patient's own country. In this scenario, access to treatment is often based on progression, which ultimately defeats the purpose of treating early. Secondly, it drives vulnerable patients to seek cheaper options in other countries or via the internet, who then potentially appear with a prescription asking to be monitored and tested, creating significant clinical dilemmas. ${ }^{[19]}$

In the case of infected PWBD, the cost should be considered in terms of lives already lost and providing 
immediate recompense for those who are still infected to live a life free of the virus. Market forces have lowered the costs of treatment with newer regimens. All individuals with bleeding disorders should be considered candidates for treatment irrespective of the stage of fibrosis within the liver. The eradication of HCV in PWBD in Europe is an idea whose time has come. ${ }^{[1]}$

\section{ACKNOWLEDGEMENTS}

The authors have advised no interests that might be perceived as posing a conflict or a bias.

This article does not contain any studies involving human participants or animals performed by any of the authors.

\section{References}

1. Makris M, Konkle BA. Hepatitis $C$ in haemophilia: time for treatment for all. Haemophilia 2017; 23(2): 180-1. doi:10.1111/ hae.13183

2. Evatt BL. The tragic history of AIDS in the hemophilia population. 1982-1984. J Thromb Haemost 2006; 4(11): 2295301. doi 10.1111/j.1538-7836.2006.02213.x.

3. O'Mahony B, Noone D, Giangrande PLF, Prihodova L. Haemophilia care in Europe - a survey of 35 countries. Haemophilia 2013; 19(4): e239-47. doi:10.1111/hae.12125.

4. World Federation of Hemophilia. Report on the Annual Global Survey 2014. 2015. Available from http://www1.wfh.org/ publications/files/pdf-1627.pdf (accessed 13 March 2018).

5. Lee YA, Friedman SL. Reversal, maintenance or progression: what happens to the liver after a virologic cure of hepatitis C? Antiviral Res 2014; 107: 23-30. doi:10.1016/j. antiviral.2014.03.012.

6. Persico M, Rosato V, Aglitti A, et al. Sustained virological response by direct antiviral agents in HCV leads to an early and significant improvement of liver fibrosis. Antivir Ther 2017. doi:10.3851/IMP3186. [Epub ahead of print].

7. El Sherif O, Afhdal N, Curry M. No one size fits all-Shortening duration of therapy with direct-acting antivirals for hepatitis C genotype 1 infection. J Viral Hepat 2017; 24(10): 808-13. doi:10.1111/jvh.12734.

8. Posthouwer D, Plug I, van der Bom JG, et al. Hepatitis C and health-related quality of life among patients with hemophilia. Haematologica 2005; 90(6): 846-50.

9. Health Protection Surveillance Centre, Ireland. National Hepatitis C Database for infection acquired through blood and blood products: 2015 Report. [2015]. Available from https:// www.hpsc.ie/a-z/hepatitis/hepatitisc/hepatitiscdatabase/ baselineandfollow-upreports/File,15238,en.pdf (accessed 13 March 2018)

10. Lövdahl S, Henriksson KM, Baghaei F, et al. Incidence, mortality rates and causes of deaths in haemophilia patients in Sweden. Haemophilia 2013;19(3): 362-9. doi:10.1111/ hae.12092.

11. Posthouwer D, Plug I, van der Bom JG, et al. Hepatitis C infection among Dutch haemophilia patients: a nationwide cross-sectional study of prevalence and antiviral treatment. Haemophilia 2005; 11(3): 270-5. doi:10.1111/j.13652516.2005.01083.x.

12. Ebeling F, Rasi V, Laitinen $H$, Krusius T. Viral markers and use of factor products among Finnish patients with bleeding disorders. Haemophilia 2001; 7(1): 42-6.

13. Irish Haemophilia Society celebrates eradication of Hepatitis C among members. Irish Examiner 22 December 2016. Available from https://www.irishexaminer.com/breakingnews/ ireland/irish-haemophilia-society-celebrates-eradicationof-hepatitis-c-among-members-769660.html (accessed 13 March 2018).

14. Cortez-Pinto H. National HCV programmes: a European approach to eliminating hepatitis $\mathrm{C}$. Presentation delivered at the European Haemophilia Consortium Round Table of Stakeholders: HCV and Haemophilia, Brussels, June 2016. Available from https://static.ehc.eu/wp-content/ uploads/09-EHC-June-RT-Presentation-Cortez-Pinto-FORDISTRIBUTION.pdf (accessed 14 May 2018).

15. Graham K. Portugal agrees to treat 13,000 Hepatitis $C$ sufferers for free. Digital Journal 8 Feb 2015. Available from http://www.digitaljournal.com/life/health/portugal-agreesto-treat-13-000-hepatitis-c-sufferers-for-free/article/425590 (accessed 13 March 2018).

16. Giangrande PLF, Peyvandi F, O'Mahony B, et al. Kreuth IV: European consensus proposals for treatment of haemophilia with coagulation factor concentrates. Haemophilia 2017; 23(3): 370-5. doi:10.1111/hae.13211.

17. Kattakuzhy S, Gross C, Emmanuel B, et al. Expansion of treatment for hepatitis $C$ virus infection by task shifting to community-based nonspecialist providers. Ann Intern Med 2017; 167(5): 311-8. doi:10.7326/M17-0118.

18. Nyalakonda $\mathrm{H}$, Utay NS. A new era of therapy for hepatitis C virus infection. Curr Opin Infect Di. 2015; 28(5): 471-8. doi:10.1097/QCO.0000000000000190.

19. Cousins S. The Tasmanian Hep C Buyers' Club. New York Times 25 July 2017. Available from https://www. nytimes. com/2017/07/25/opinion/the-tasmanian-hep-c-buyers-club. html (accessed 13 March 2018). 


\section{APPENDIX}

Figure A1: Survey questions sent out to the European Haemophilia Consortium (EHC) membership

\section{SECTION 1: RESPONDENT IDENTIFIER}

In this first section, we want to identify who is responding to the survey.

Please state the country for which you are reporting data and your identity.

\section{Question 1: For which country are you reporting data?}

Question 2: You are:

$\square$ An EHC NMO representative

$\square$ A healthcare professional

$\square$ Other (please specify)

Question 3: Please state:

- Your name:

- Your affiliation (i.e. the name of the organisation that you are representing in this survey):

- Your role or title within the organisation stated above:

- Your email address:

- Your telephone number (please include the country code):

- Your address (please state the name of your street and street number, city, postcode and country):

\section{SECTION 2: ON PEOPLE WITH BLEEDING DISORDERS AND HCV IN YOUR COUNTRY}

When we talk about 2nd generation DAAs we refer to all new products launched after telaprevir and boceprevir, which are often called 1st generation DAAs

Question 4: Please state how many people in your country with bleeding disorders were also infected with HCV?

If you do not have the exact number, you can provide an estimated number under the 2nd column. Please do let us know where your data comes from. This will help us in legitimising the findings of the survey.

$\begin{array}{ll}\text { EXACT NUMBER SOURCE OF THE DATA } & \text { ESTMATED NUMBER SOUR }\end{array}$

Question 5: Of the number of people mentioned in question 4, how many:

- Are still alive?

- Were co-infected with HIV (please give a percentage of patients infected with HCV who were also infected with HIV)? 
Question 6: With regard to patients with bleeding disorders that were infected with HCV in your country, please state:

- How many patients with bleeding disorders and HCV in your country have cleared HCV spontaneously? (i.e. became HCV RNA PCR negative without treatment)

- How many have achieved Sustained Virologic Response (SVR)/ cure through treatment?

- How many have achieved SVR using 2nd generation DAA products provided by the state or through clinical trials?

Question 7: In your country, how many people with bleeding disorders were infected with HCV:

For the answer here below, you can choose to give a) the exact number of patients (if you have accurate records of this) OR b) an estimated number (2nd column) OR c) an estimated percentage (3rd column).

\begin{tabular}{l|l|l|l|}
\hline Remain to be cured? & & & \\
\hline Had a liver transplant? & & & \\
\hline & & \\
\hline $\begin{array}{l}\text { Developed hepatocellular } \\
\text { carcinoma? }\end{array}$ & & & \\
\hline $\begin{array}{l}\text { Were financially } \\
\text { compensated by your } \\
\text { government? }\end{array}$ & & & \\
\hline
\end{tabular}

\section{SECTION 3: ON HCV CARE IN YOUR COUNTRY}

Question 8: Are people with bleeding disorders and HCV routinely tested for progression of liver diseases at their treatment centre?

$\square$ Yes

$\square$ No

If you answer no, please skip directly to question 11.

Question 9: Please respond only if you have answered yes in question 8.

How often are these tests performed?

$\square$ Every six months

$\square$ Every year

$\square$ Once in every two years

$\square$ Other. Please specify:

Question 10: Please respond to this question if you have answered yes to question 8.

How are these tests performed?

$\square$ With liver biopsy

$\square$ With fibro-scan

$\square$ With fibro-test

$\square$ Other (please specify): 
Question 11: What is the national standard of HCV treatment in your country?

What is the level of reimbursement?

We refer here to treatments that provided by the national or regional healthcare system.

\begin{tabular}{|c|c|c|c|c|}
\hline & $\begin{array}{l}\text { IS NOT AVAILABLE } \\
\text { IN MY COUNTRY }\end{array}$ & $\begin{array}{l}\text { IS AVAILABLE IN MY } \\
\text { COUNTRY BUT THE } \\
\text { PATIENT NEEDS } \\
\text { TO FULLY PAY FOR } \\
\text { THIS TREATMENT } \\
\text { (NO GOVERNMENT } \\
\text { REIMBURSEMENT) }\end{array}$ & $\begin{array}{l}\text { IS AVAILABLE IN MY } \\
\text { COUNTRY AND THE } \\
\text { PATIENT NEEDS TO } \\
\text { CO-PAY FOR THIS } \\
\text { TREATMENT }\end{array}$ & $\begin{array}{l}\text { IS AVAILABLE IN } \\
\text { MY COUNTRY } \\
\text { AND IT IS FULLY } \\
\text { COVERED BY } \\
\text { THE NATIONAL } \\
\text { HEALTHCARE } \\
\text { SYSTEM }\end{array}$ \\
\hline $\begin{array}{l}\text { PEG-interferon } \\
\text { +ribavirin }\end{array}$ & & & & \\
\hline $\begin{array}{l}\text { PEG-interferon } \\
\text { +ribavirin+telaprevir / } \\
\text { boceprevir }\end{array}$ & & & & \\
\hline $\begin{array}{l}\text { PEG-interferon } \\
\text { +ribavirin +sofosbuvir }\end{array}$ & & & & \\
\hline $\begin{array}{l}\text { 2nd generation DAAs } \\
\text { (e.g.: sofosbuvir, } \\
\text { velpatasvir, elbasvir, } \\
\text { grazoprevir, daclatasvir, } \\
\text { ombitasvir, paritaprevir, } \\
\text { ritonavir, dasabuvir, } \\
\text { ledipasvir) }\end{array}$ & & & & \\
\hline
\end{tabular}

Question 12: Is your government prioritising access to treatments selected in question 11:

- Based on the progression of the liver disease? (e.g. fibrosis stages, cirrhosis, liver cancer?)

$\square$ Yes / $\square$ No

- For people with bleeding disorders and HCV?

$\square$ Yes / $\square$ No

Question 13: In your country, what is the current cost of a course of 12 weeks treatment with sofosbuvir or Harvoni (ledipasvir+sofosbuvir)?

If you are aware of the current price of other HCV treatments in your country, please list them here:

Question 14: Has your country undergone price negotiations/tender for bulk purchase of DAAs?

Question 15: Does your country have a national HCV treatment programme?

$\square$ Yes

$\square$ No

Question 16: How is treatment for people with haemophilia and HCV administered in your country?

$\square$ Through the general practitioners

$\square$ Through the haemophilia treatment centre

$\square$ Through specialised hepatology services in hospitals

$\square$ Other - Please specify:

Question 17: Is there any additional information on access to HCV treatment or cost of treatment in your country that you wish to let us know? 
Table A1: Countries providing exact figures, estimates or no data on total population infected with HCV (question 4) and infection status (question 5)

\begin{tabular}{|c|c|c|c|}
\hline COUNTRY & $\begin{array}{l}\text { TOTAL INFECTED } \\
\text { WITH HCV }\end{array}$ & $\begin{array}{l}\text { INFECTED WITH HCV } \\
\& \text { STILL ALIVE }\end{array}$ & $\begin{array}{l}\text { CO-INFECTED } \\
\text { WITH HIV }\end{array}$ \\
\hline Albania & Est. & $N D^{*}$ & Exact \\
\hline Austria & Exact & $N D^{*}$ & Exact \\
\hline Azerbaijan & Est. & $N D^{*}$ & ND \\
\hline Belarus & Est. & $N D^{*}$ & ND \\
\hline Bosnia \& Herzegovina & Est. & $N D^{*}$ & ND \\
\hline Bulgaria & Est. & $N D^{*}$ & ND \\
\hline Cyprus & Est. & Exact & Exact \\
\hline Czech Republic & Est. & Exact & Exact \\
\hline Denmark & Exact & $N D^{*}$ & Exact \\
\hline Finland & Est & $N D^{*}$ & Exact \\
\hline France & Exact & $N D^{*}$ & Exact \\
\hline Germany & Est. & Exact & Exact \\
\hline Greece & Est. & Exact & Exact \\
\hline Hungary & Exact & $N D^{*}$ & Exact \\
\hline Ireland & Exact & Exact & Exact \\
\hline Italy & Est. & Exact & Exact \\
\hline Latvia & ND & $\mathrm{ND}^{*}$ & ND \\
\hline Lithuania & Est. & $N D^{*}$ & Exact \\
\hline Macedonia & Est. & $N D^{*}$ & Exact \\
\hline Montenegro & Exact & $N D^{*}$ & Exact \\
\hline The Netherlands & Exact & $N D^{*}$ & ND \\
\hline Poland & ND & ND* & ND \\
\hline Portugal & Est. & $N D^{*}$ & Exact \\
\hline Romania & Est. & $N D^{*}$ & ND \\
\hline Slovakia & Exact & Exact & Exact \\
\hline Slovenia & Exact & Exact & Exact \\
\hline Sweden & Exact & Exact & Exact \\
\hline Switzerland & Est. & ND* & ND \\
\hline Ukraine & Est. & $N D^{*}$ & Exact \\
\hline United Kingdom & Est. & $N D^{*}$ & Exact \\
\hline
\end{tabular}

Est.: Estimated figure

Exact: Exact figure

ND: No data

ND*: No data or incomplete data 
Table A2: Countries providing exact figures, estimates or no data on spontaneous HCV clearance/SVR (question 6)

\begin{tabular}{|c|c|c|c|}
\hline COUNTRY & $\begin{array}{l}\text { SPONTANEOUS } \\
\text { CLEARANCE }\end{array}$ & SVR & $\begin{array}{l}\text { SVR WITH SECOND- } \\
\text { GENERATION DAAS }\end{array}$ \\
\hline Albania & ND & ND & ND \\
\hline Austria & ND & ND & ND \\
\hline Azerbaijan & Exact & Exact & ND \\
\hline Belarus & ND & ND & ND \\
\hline Bosnia \& Herzegovina & ND & ND & ND \\
\hline Bulgaria & Exact & Exact & ND \\
\hline Cyprus & ND & Exact & Exact \\
\hline Czech Republic & Exact & Exact & Exact \\
\hline Denmark & ND & Exact & Exact \\
\hline Finland & ND & ND & Exact \\
\hline France & ND & ND & ND \\
\hline Germany & Exact & Exact & Exact \\
\hline Greece & Est. & Est. & Est. \\
\hline Hungary & Est & Est. & Exact \\
\hline Ireland & Exact & Exact & Exact \\
\hline Italy & ND & ND & ND \\
\hline Latvia & ND & ND & ND \\
\hline Lithuania & Est. & Est. & ND \\
\hline Macedonia & ND & Exact & ND \\
\hline Montenegro & Exact & Exact & ND \\
\hline The Netherlands & Est. & ND & ND \\
\hline Poland & ND & ND & ND \\
\hline Portugal & ND & Exact & ND \\
\hline Romania & ND & ND & ND \\
\hline Slovakia & Exact & Exact & ND \\
\hline Slovenia & Exact & Exact & ND \\
\hline Sweden & Exact & Exact & ND \\
\hline Switzerland & ND & ND & ND \\
\hline Ukraine & ND & ND & ND \\
\hline United Kingdom & Est. & ND & ND \\
\hline
\end{tabular}

Est.: Estimated figure Exact: Exact figure

ND: No data 
Table A3: Countries providing exact figures, estimates or no data on PWBD who remain to be successfully treated, had a liver transplant, developed hepatocellular carcinoma ( $\mathrm{HCC}$ ) and have been financially compensated (question 7)

\begin{tabular}{|c|c|c|c|c|}
\hline COUNTRY & $\begin{array}{l}\text { REMAIN TO } \\
\text { BE TREATED } \\
\text { SUCCESSFULLY }\end{array}$ & $\begin{array}{l}\text { HAD A LIVER } \\
\text { TRANSPLANT }\end{array}$ & DEVELOPED HCC & $\begin{array}{l}\text { HAVE BEEN } \\
\text { FINANCIALLY } \\
\text { COMPENSATED }\end{array}$ \\
\hline Albania & Est. & ND & ND & Est. \\
\hline Austria & ND & ND & ND & ND \\
\hline Azerbaijan & ND & ND & ND & ND \\
\hline Belarus & Est. & ND & ND & ND \\
\hline Bosnia \& Herzegovina & ND & ND & ND & ND \\
\hline Bulgaria & Exact & ND & ND & ND \\
\hline Cyprus & Est. & Exact & Exact & Exact \\
\hline Czech Republic & Exact & Est. & Est. & Est. \\
\hline Denmark & Est. & ND & ND & Exact \\
\hline Finland & Exact & Exact & ND & ND \\
\hline France & Est. & Exact & Exact & Exact \\
\hline Germany & Exact & Exact & Exact & Exact \\
\hline Greece & Est. & Est. & Est. & Exact \\
\hline Hungary & Est. & Exact & Exact & Exact \\
\hline Ireland & Exact & Exact & Est. & Exact \\
\hline Italy & Est. & Est. & ND & Est. \\
\hline Latvia & ND & ND & ND & ND \\
\hline Lithuania & Est. & Exact & Exact & ND \\
\hline Macedonia & ND & ND & ND & Exact \\
\hline Montenegro & Exact & Exact & Exact & Exact \\
\hline The Netherlands & ND & ND & ND & Exact \\
\hline Poland & ND & ND & ND & Exact \\
\hline Portugal & Exact & Est. & Est. & Exact \\
\hline Romania & ND & ND & ND & ND \\
\hline Slovakia & Exact & Exact & Exact & Exact \\
\hline Slovenia & Exact & Exact & Exact & Exact \\
\hline Sweden & Exact & ND & ND & Exact \\
\hline Switzerland & ND & ND & ND & ND \\
\hline Ukraine & Est. & Exact & ND & ND \\
\hline United Kingdom & ND & ND & ND & Est. \\
\hline
\end{tabular}

Est.: Estimated figure

Exact: Exact figure

ND: No data 


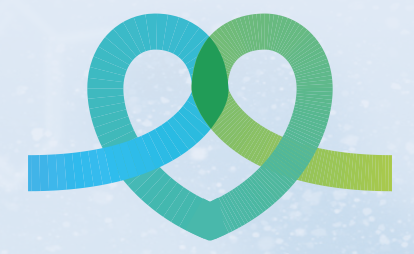

\section{The Journal of Haemophilia Practice}

An open-access journal for sharing experience in the care of people with bleeding disorders 